\title{
ДИАГНОСТИКА ПОВРЕЖДЕННЫХ УЧАСТКОВ ТРУБОПРОВОДОВ ВОЛНОВЫМ ЗОНДИРОВАНИЕМ
}

@ В.Ш.Шагапов, Э.В.Галиакбарова, 3.Р.Хакимова

Shagapov@rambler.ru,emi.galiakbar@yandex.ru,zulfya.hakimova@yandex.ru

\section{УДК $532 / 529.534 .2$}

DOI: $10.33184 /$ mnkuomsh2t-2021-10-06.98.

Для обнаружения повреждений при транспорте углеводородных жидкостей или газов предложено создавать зондирующий импульс давления во флюиде, заполняющем трубопровод. Построена теоретическая модель распространения импульса конечной длительности по трубопроводу с повреждениями типа коррозионных проржавлений, трещин и пробоин, пробок. Рассмотрены случаи наземного и подземного расположения трубопроводов. Получены системы интегро-дифференциальных уравнений. Исследованы дисперсионные уравнения, коэффициенты отражения и прохождения в зависимости от типа повреждения. Изучена динамика импульсов в трубопроводе с поврежденными участками на основе быстрого преобразования Фурье.

Ключевые слова: интегро-дифференциальные уравнения, гармоническая волна, быстрое преобразование Фурье.

\section{Diagnostics of damaged pipeline sections by wave probing}

To detect damage in pipelines during the transport of hydrocarbon liquids or gases, it is proposed to create a probing pressure pulse in the fluid filling the channel. A theoretical model of the propagation of pulses of finite duration through a pipeline with damages such as corrosive rusting, cracks and holes, plugs has been built. Cases of aboveground and underground location of pipelines are considered. Systems of integro-differential equations are obtained. Dispersion equations, reflection and transmission coefficients are derived depending on the type of damage. The dynamics of impulses in a pipeline with damaged sections was studied based on the fast Fourier transform.

Исследование выполнено за счет гранта Российского научного фонда № 21-1100207, https://rscf.ru/project/21-11-00207/

Шагапов Владислав Шайхулагзамович, д.ф.-м.н., профессор, Институт механики им. Р.Р. Мавлютова УФИЦ РАН (Уфа, Россия); Vladislav Shagapov (Mavlutov Institute of Mechanics, Investigation Center, R.A.S., Ufa, Russia)

Галиакбарова Эмилия Вильевна, к.ф.-м.н., доцент, Институт механики им. Р.P. Мавлютова УФИЦ РАН, УГНТУ (Уфа, Россия); Emiliya Galiakbarova(Mavlutov Institute of Mechanics, Investigation Center, R.A.S.,Ufa State Petroleum Technological University, Ufa, Russia)

Хакимова Зульфия Разифовна, Институт механики им. Р.Р. Мавлютова УФИЦ РАН, УГНТУ (Уфа, Россия); Zulfiya Khakimova (Mavlutov Institute of Mechanics, Investigation Center, R.A.S.,Ufa State Petroleum Technological University, Ufa, Russia) 
Keywords: integro-differential equations, harmonic wave, fast Fourier transform.

Рассматривается трубчатый канал (трубопровод), заполненный газом или жидкостью, содержащий поврежденный участок протяженностью $l_{\delta}$ в виде щелей, трещин, пробоин или пробок. На конце трубопровода, радиуса $a$ создается сканирующий импульс давления длительностью $l_{\delta}$ и длиной волны $\lambda$. Приняты допущения [1]: $\lambda \gg l_{\delta}, \lambda>2 a$, $(\lambda=2 \pi C / \omega,-$ скорость звука в среде). Повреждения рассматриваются отражающей поверхностью, возмущения давления и скорости - функции одной пространственной координаты $z$ и времени $t$; ось $\mathrm{Oz}$ направлена по оси симметрии трубопровода, начало отсчета $(z=0)$ совпадает с поврежденным участком; расстояние до повреждения равно $l$.

Импульсный сигнал при распространении по трубопроводу затухает. Принята модель[2], в которой вязкость и теплопроводность флюида проявляются в тонком слое вблизи внутренней поверхности стенки трубопровода $\left(a \gg 2 \sqrt{\nu^{(j)} / \omega}, j=T, \nu\right.$, где $\nu^{(j)}, j=T, \nu-$ коэффициент температуропроводности и кинематической вязкости газа или жидкости).

Решение ищется в виде затухающих гармонических волн.

В работах [2-5] получены дисперсионные уравнения, которые проанализированы для различных газов, жидкостей, заполняющих канал, характеристик канала, выведены коэффициенты отражения и прохождения в зависимости от типа повреждения. Динамика импульсного сигнала конечной длительности изучалась с помощью быстрого преобразования Фурье [6-7].Теоретические построения положены в основу патента на изобретение [8].

\section{Литература}

1. Исакович М.А. Общая акустика. М.: - Наука,1973. 496 с.

2. Шагапов В.Ш., Галиакбарова Э.В., Хакимова З.Р. К теории акустического сканирования трубопроводов с поврежденными участками // Труды института механики им. Р.Р. Мавлютова. Электронный журнал теоретической механики. 2016. Т. 11, №2. С. 180-188.

3. Шагапов В.Ш., Галиакбарова Э.В., Хакимова З.Р. К теории акустического зондирования трубчатых каналов, содержащих участки с нарушением герметичности// Инженерно физический журнал. 2018. Т. 91. № 3, С. 709 -719 .

4. Шагапов В.Ш., Галиакбарова Э.В.,Хусаинов И.Г., Хакимова З.Р. Акустическое сканирование поврежденных трубопроводов, находящихся в грунте// Прикладная механика и техническая физика. 2018. Т. 59. № 4. С. 169-178.

5. Шагапов В.Ш., Галиакбарова Э.В., Хакимова З.Р.Динамика импульсных сигналов в трубопроводе, заполненном метано-парокапельной смесью и 
подверженной газогидратным отложениям// Инженерно- физический журнал. 2021. Т. 94. № 3. С. $698-706$.

6. Ебимов B.A.Математический анализ (специальные разделы),ч.I, M: Высшая школа. 1980.279 с.

7. Губайдуллин А.А, Болдырева О.Ю. Компьютерное моделирование волновых процессов в пористых средах// Вестник кибернетики. 2016. № 2(22). C. $103-111$.

8. Галиакбаров В.Ф., Галиакбарова Э.В., Ковшов В.Д., Аминев Ф.М., Хажимова З.Р. Система контроля состояния трубопровода. Пат.2606719 С1 РФ, F17D5/00, опубл. 10.01.2017, Бюл. № 1. 